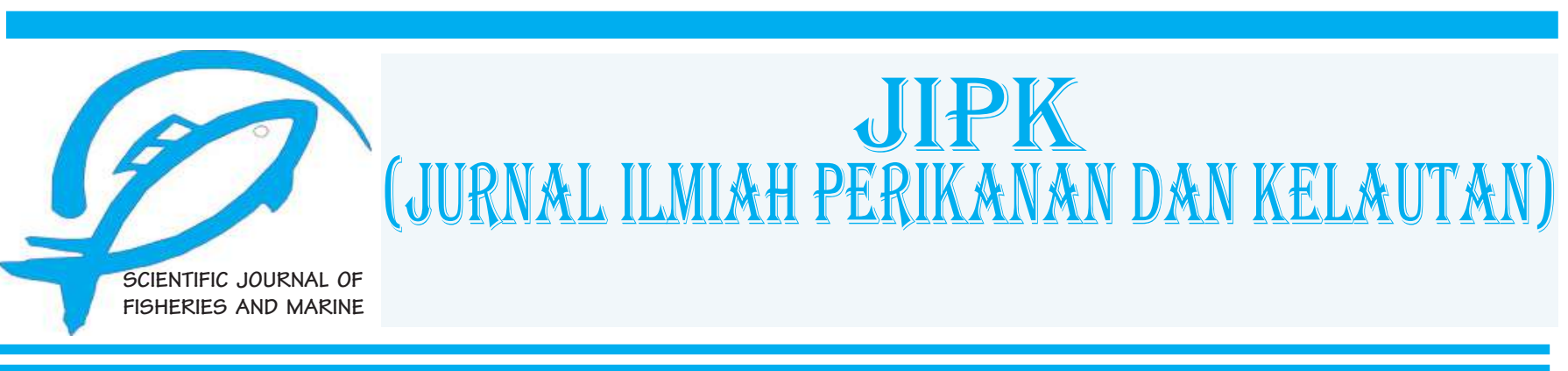

Research Article

\title{
Application of Probiotics for Organic Matter and Enhancement of Growth Performance in White Shrimp (Litopenaeus vannamei)
}

\author{
Mohammad Jefrii ${ }^{1}$, Woro Hastuti Satyantini ${ }^{2}$ iD , Adriana Monica Sahidu ${ }^{3}$, Daruti Dinda Nindarwi ${ }^{2}$ Rozi $^{2}$ \\ ${ }^{1}$ Program Studi Akuakultur, Fakultas Perikanan dan Kelautan, Universitas Airlangga, Indonesia \\ ${ }^{2}$ Departemen Manajemen Kesehatan Ikan dan Budidaya Perairan, Fakultas Perikanan dan Kelautan, Universitas Airlangga, Indonesia \\ ${ }^{3}$ Departemen Kelautan, Fakultas Perikanan dan Kelautan, Universitas Airlangga, Indonesia
}

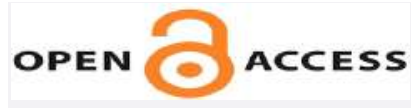

\section{ARTICLE INFO}

Received: Desember 25, 2019

Accepted: February 15, 2020

Published: March 11, 2020

*) Corresponding author:

E-mail:woro_hs@fpk.unair.ac.id

Keywords:

Bacillus sp.

Pseudomonas sp.

organic matter

growth performances

white shrimp

This is an open access article under the CC BY-NC-ND license (http://creativecommons.org/licenses/by-nc-nd/4.0/)

\begin{abstract}
Intensive shrimp farming has raised environmental issues due to aquaculture pollution, which is caused by uneaten feed, feces, organic matter, and toxic compounds (ammonia and H2S). One way to solve this issue is by using probiotics. Thus, this study aimed at investigating the effect of probiotic administration (Pseudomonas sp. and Bacillus sp.) at varying concentrations on total organic matter in the rearing water, feed conversion ratio, feed efficiency, and growth rate of white shrimp (Litopenaeus vannamei). This study used a Completely Randomized Design consisting of four treatments: T0 (without the probiotic supplementations), $\mathrm{T} 1$ (probiotics at $10^{6} \mathrm{CFU} / \mathrm{ml}$ ), T2 (probiotics at $10^{7} \mathrm{CFU} / \mathrm{mL}$ ), T3 (probiotics at $10^{8} \mathrm{CFU} / \mathrm{mL}$ ) with three replicates each. The results showed that the administration of probiotics at different concentrations had a significant effect on the total amount of organic matter, feed conversion ratio, feed efficiency, and specific growth rate of white shrimp. Administration of probiotics at a concentration of $10^{7} \mathrm{CFU} / \mathrm{ml}$ had the lowest organic matter in the rearing water, $138 \mathrm{mg} / \mathrm{Lt}$. While probiotic administration at $10^{8} \mathrm{CFU} / \mathrm{ml}$ gave the lowest feed conversion ratio (1.22), the highest feed efficiency $(81.57 \%)$ and the best growth rate $(2.25 \%$ / day). This research suggests that the administration of $10^{7}-10^{8} \mathrm{CFU} / \mathrm{ml}$ probiotics could be applied to reduce organic content in the rearing water and improve the growth performances of white shrimp.
\end{abstract}

Cite this as: Jefri, M., Satyantini., W. H., Sahidu, A. M., Nindarwi, D. D., \& Rozi. (2020). Application of Probiotics for Organic Matter and Enhancement of Growth Performance in White Shrimp (Litopenaeus vannamei). Jurnal Ilmiah Perikanan dan Kelautan, 12(1): 97-104. http://doi.org/10.20473/jipk.v12i1.16618 


\section{Introduction}

Shrimp production could be increased by an intensive aquaculture system, in which more inputs, such as shrimp larvae and feed are required (Ekasari, 2009). However, the intensive aquaculture system has negative impacts, such as increasing the amount of organic matter, food waste and feces, increasing the density of phytoplankton, more toxic compounds such as $\mathrm{NH}_{3}$ and $\mathrm{H}_{2} \mathrm{~S}$ and increasing disease transmission in cultured organisms (Herdianti et al., 2015). Environmental factors, especially water quality determine the success of shrimp farming. Prevention of water quality deterioration can be achieved by giving probiotic from the beginning of the culture period to degrade organic material in the pond (Irianto, 2003). The application of probiotics in aquaculture has been used to maintain rearing water quality in several fish species such as tilapia (Wang et al., 2008), snapper (Rengpipat et al., 2008), and white shrimp (Kumar et al., 2016). Furthermore, Yuvaraj and Karthik (2015) stated that the latest effort to improve water quality in aquaculture is the application of probiotics and or enzymes in shrimp ponds.

Pseudomonas sp. and Bacillus sp. are bacterial decomposers (biodegradation) or what is called probiotic bacteria. According to Edy and Busono (2000), microorganisms that have a capacity to decompose organic materials in rearing water could be classified as products of biotechnology. These types of bacteria were generally obtained from nature and had been selected due to their capacity to help the process of purification of organic materials in the water. Bacteria could be used to remove unwanted components in the aquaculture media, such as ammonium. The main strength and driving force for the operation of this system is the intensive growth of heterotrophic bacteria (Avnimelech, 2006).

Yudiarti et al. (2010) documented that the administration of probiotics could be reduce the total population of Vibrio, total ammonia levels, and organic matter. According to Aslamyah (2011), the application of bioremediation probiotic Bacillus sp. with a concentration of $0.5 \mathrm{ppm}$ per week in the culture medium could be improve the water quality and the activity of the $\alpha$-amylase and protease enzymes, as well as could be increase the survival and growth of white shrimp. A study by Eissa et al. (2014) showed that the administration of $P$. flourescens at a concentration of $10^{8} \mathrm{CFU} / \mathrm{g}$ could protect cultured organisms against pathogenic bacteria in tilapia. Linggarjati et al. (2013) reported that the use of Bacillus sp. with a density of $10^{6} \mathrm{CFU} / \mathrm{ml}$ reduced the content of ammonia $\left(\mathrm{NH}_{3}\right)$, nitrite $\left(\mathrm{NO}_{2}\right)$, and the total Vibrio sp.. While Wang and $\mathrm{Gu}(2010)$ also showed that the administration of probiotic Lactobacillus acidophilus RS058, Rhodopseudomonas palustris GH642, and Bacillus coagulans NJ105 respectively in white shrimp gave daily growth and specific growth rates higher than controls (without probiotics). The results in the study of Cha et al. (2013) showed that the administration of $B$. subtilis had a beneficial effect on growth performance, non-specific immunity, and disease resistance in flounder fish and maintenance water quality.

This study was aimed to investigate the effect of probiotic administration (Pseudomonas sp. and Bacillus sp.) at the different concentration on the amount of organic matter in rearing water and growth performance of white shrimp (L vannamei).

\section{Materials and Methods}

\subsection{Samples collection}

This research was performed in the Laboratory of Fish Health Management, the Brackish Water Aquaculture Development Centre, Jepara, Indonesia from September 2018 to February 2019. White shrimps (DOC $35,8-9 \mathrm{~cm}$ length, and weighing 5-7 g) were collected from pond farmers around the Brackish Water Development Centre, Jepara. The shrimps were in healthy condition and not infected by a disease such as Vibrio.

\subsection{Probiotic Isolates}

Three probiotics (Pseudomonas sp., Bacillus sp. $\mathrm{SDB}_{14}$, dan Bacillus sp. $\mathrm{SDB}_{16}$ ) originated from sediment of shrimp ponds and were not toxic. Each bacterial isolate was isolated separately using sterile Tryptic soya Broth (TSB) and incubated at $37^{\circ} \mathrm{C}$ for $24 \mathrm{~h}$.

\subsection{Experimental Design}

The present study used completely randomized design (CRD) with four treatments T0 (no probiotic addition), T1 (probiotic at a concentration of $10^{6} \mathrm{CFU} / \mathrm{ml}$ ), $\mathrm{T} 2$ (probiotic at $10^{7} \mathrm{CFU} / \mathrm{ml}$ ), T3 (probiotic at $10^{8} \mathrm{CFU} /$ $\mathrm{ml}$ ) and each treatment had three replicates.

\subsection{Probiotic Preparation}

Pseudomonas sp., Bacillus sp. SDB14, and Bacillus sp. SDB16 were cultured in a modified culture media. The modified media were made by preparing $50 \mathrm{ml}$ of sterile $t o f u$-waste liquid, $25 \mathrm{ml}$ molasses, 6 g glucose solution, and $15 \mathrm{~g} \mathrm{NaCl}$ dissolved in $1 \mathrm{~L}$ distilled water. Then, $100 \mathrm{~g}$ skim milk was dissolved in $1 \mathrm{~L}$ distilled water and sterilized by heating in a water bath at a temperature of $70-80{ }^{\circ} \mathrm{C}$ for 10 minutes. After the sterilization process was completed, a $10 \%$ skim milk solution was added into $900 \mathrm{ml}$ of the modified culture media. Thereafter, the probiotic isolates were isolated from Pseudomonas sp., Bacillus sp. SDB14 and Bacillus sp. SDB16 of $10^{5} \mathrm{CFU} / \mathrm{ml}$ each. 
JIPK. Volume 12 No 1. April 2020 / Application of Probiotics for Organic Matter and Enhancement of Growth...

\subsection{Probiotic Administration}

The administration of probiotics was conducted through rearing water twice a week with a dose of $1 \mathrm{ml} /$ liter and adjusted according to the treatments $10^{6} \mathrm{CFU} /$ $\mathrm{ml}, 10^{7} \mathrm{CFU} / \mathrm{ml}$, and $10^{8} \mathrm{CFU} / \mathrm{ml}$.

\subsection{Culturing of White Shrimp}

The white shrimps were cultured in brackish water with 15 ppt salinity (Suharyadi, 2011), and fed with commercial pellet containing $35 \%$ protein content (Nur, 2011). The feeding was performed four times a day (Widagdo, 2011), with the feeding rate at 3\% BW per day. The feces secreted by white shrimps was siphoned off every seven days.

\subsection{Measured Parameters}

The main parameters observed in this study were organic material using the titrimetry method, feed conversion ratio (FCR) (Standen et al., 2015), feed efficiency (EP) (Effendi, 2003; Dahlan et al., 2017), and specific growth rate (SGR) (Standen et al., 2015). While supporting parameters were temperature, $\mathrm{pH}$, and dissolved oxygen (DO).

\subsection{Measurements of Observed Parameter}

The amount of organic matter was measured by using a titration method (SNI 06-6989.22-2004). Bodyweight of white shrimp was measured using a ruler, and the total weight was measured using an analytical scale, and both parameters were measured every seven days. The feed conversion ratio and feed efficiency were calculated at the end of the study. While $\mathrm{pH}$ was measured by $\mathrm{pH}$ pen, DO with YSI DO meter, salinity with a refractometer, and the temperature with a thermometer. Water quality measurements were read out every day for 28 days.

\subsection{Data Analysis}

Data were analyzed using Analysis of Variance (ANOVA) to determine the effect of each treatment (Kusriningrum, 2008). When the ANOVA test results were significantly different, the Duncan test (DMRT) was performed to determine the difference among treatments.

\section{Result and Discussion}

The main source of organic matter in aquaculture pond is organic fertilizer, feces, uneaten feed, phytoplankton, zooplankton and benthos, zooplankton, and benthos (Boyd, 2016).

The measurement of organic matter is very important in this present study to investigate the role of administered probiotics to reduce organic matter content in the shrimp aquaculture system and contribute to the growth performance of shrimps. The result of organic content measurement during this study is presented in Table 1.

There were no significant differences in the total organic matter of the shrimp's rearing water among all treatments (T0, T1, T2, and T3), which were observed on day $7(p>0.05)$. On day $14^{\text {th }}$, organic matter on the rearing water of T0 was not significantly different $(p>$ 0.05 ) from the organic matter in rearing water of $\mathrm{T} 1$ and T3. However, total organic matter in the rearing water of T1 was significantly different from that in T2 (p $<0.05$ ). On the $21^{\text {st }}$ day, the results showed that organic matter in $\mathrm{T} 1$ was significantly different $(\mathrm{p}<0.05)$ from that of T2 but not significantly different from those of $\mathrm{T} 0$ and T3, ( $>0.05)$. On day 28 , organic content in the control water (T0) was significantly different from T2 (p $<0.05)$, but organic matter in T2 $(138.68 \mathrm{mg} / 1)$ and was not significantly different from T3 $(170.63 \mathrm{mg} / 1)$ and T0 (177.33 mg / 1) ( $\mathrm{p}>0.05)$.

The total amount of organic matter had increased in the rearing water without probiotics administration (T0) until the end of the culture period. While the rearing water with the addition of probiotics showed lower values than the control (T0) except in T1 (probiotic at a concentration of $\left.10^{6} \mathrm{CFU} / \mathrm{ml}\right)$. Organic content in $\mathrm{T} 2$ was lower compared to $\mathrm{T} 1\left(10^{6} \mathrm{CFU} / \mathrm{ml}\right)$ and $\mathrm{T} 3$ $\left(10^{8} \mathrm{CFL} / \mathrm{ml}\right)$ until the end of culture. These results are in agreement with the result of Yuvaraj and Karthik (2015), in which mineralization of organic matter and getting rid of unwanted waste compounds can be performed by microorganisms.

Table 1. Organic-matter content in rearing water of white shrimp aquaculture after administration of probiotics.

\begin{tabular}{cccccc}
\hline \multirow{2}{*}{ Treatment } & \multicolumn{5}{c}{ Organic content in the rearing water $(\mathbf{m g} / \mathbf{l} \pm$ SD) } \\
\cline { 2 - 6 } & \multicolumn{1}{c}{ Day-0 } & \multicolumn{1}{c}{ Day-7 } & Day-14 & \multicolumn{1}{c}{ Day-21 } & Day-28 \\
\cline { 2 - 6 } T0 & $88,71 \pm 0,00$ & $156,73^{\mathrm{a}} \pm 13,68$ & $172,49^{\mathrm{a}} \pm 8,40$ & $170,45^{\mathrm{ab}} \pm 19,27$ & $177,33^{\mathrm{ab}} \pm 21,77$ \\
T1 & $78,87 \pm 0,00$ & $152,69^{\mathrm{a}} \pm 39,00$ & $138,57^{\mathrm{ab}} \pm 31,36$ & $194,94^{\mathrm{a}} \pm 24,47$ & $212,70^{\mathrm{a}} \pm 13,17$ \\
T2 & $85,44 \pm 0,00$ & $127,57^{\mathrm{a}} \pm 13,95$ & $129,85^{\mathrm{b}} \pm 8,88$ & $139,10^{\mathrm{b}} \pm 23,94$ & $138,68^{\mathrm{b}} \pm 33,06$ \\
T3 & $89,31 \pm 0,00$ & $150,66^{\mathrm{a}} \pm 25,44$ & $163,77^{\mathrm{ab}} \pm 8,88$ & $148,80^{\mathrm{ab}} \pm 38,35$ & $170,63^{\mathrm{ab}} \pm 25,93$ \\
\hline
\end{tabular}


According to Boyd (2016), the decomposition of organic material by microbes depends on several factors, including water temperature, $\mathrm{pH}, \mathrm{DO}$ and composition of the organic material itself. Bacteria and other decomposing microorganisms degrade organic matter quickly at temperatures ranging from $30-35^{\circ} \mathrm{C}$. Water temperature measured in the present study was below $30^{\circ} \mathrm{C}$ (Table 5), and this caused low performance of probiotic bacteria in decomposing the organic matter. This could be seen from the measurement results of organic matter at the end of the culturing period which was ranging from $138.68-212.0 \mathrm{mg} / 1$.
On the day $28^{\text {th }}$ day, the lowest organic matter was found in the rearing water of T2, $138.68 \mathrm{mg} / 1$, where the results were still below the maximum limit of organic matter for white shrimp culture. This is consistent with the statement of Adiwijaya et al. (2008) in which states that the maximum limit for organic matter is $<150.00 \mathrm{mg} / 1$. According to Putra et al., (2014), organic matter content in the culture media with the range of $41.14-162.45 \mathrm{mg} / 1$ and produced ammonia $\sim 0.000$ $\mathrm{mg} / \mathrm{l}$. Thus, it is suggested that probiotic bacteria with a density of $10^{7} \mathrm{CFU} / \mathrm{ml}$ (T2) could be degrade and reduce total organic matter in shrimp rearing water.

Table 2. The feed conversion ratio of white shrimp (L. vannamei) supplemented with probiotic at different concentrations.

\begin{tabular}{ccccc}
\hline \multirow{2}{*}{ Treatments } & \multicolumn{3}{c}{ Feed Conversion Ratio } & \multirow{2}{*}{ Mean \pm SD } \\
\cline { 2 - 4 } & \multicolumn{3}{c}{ Replications } & \\
\cline { 2 - 4 } & I & II & III & $2.60^{\mathrm{a}} \pm 0.12$ \\
T0 & 2.58 & 2.74 & 2.5 & $1.75^{\mathrm{b}} \pm 0.21$ \\
T1 & 1.99 & 1.61 & 1.65 & $1.87^{\mathrm{b}} \pm 0.35$ \\
T2 & 1.46 & 2.11 & 2.04 & $1.22^{\mathrm{c}} \pm 0.01$ \\
T3 & 1.22 & 1.22 & 1.23 & \\
\hline
\end{tabular}

Table 3. Feed efficiency of white shrimp (L. vannamei) supplemented with probiotics at three diffent concentrations

\begin{tabular}{ccccc}
\hline \multirow{2}{*}{ Treatments } & \multicolumn{3}{c}{ Feed Efficiency (\%) } & \multirow{2}{*}{ Mean \pm SD } \\
\cline { 2 - 4 } & \multicolumn{3}{c}{ Replications } \\
\cline { 2 - 4 } & I & II & III & $38.36^{\mathrm{c}} \pm 1.72$ \\
T0 & 38.67 & 36.47 & 39.85 & $57.50^{\mathrm{b}} \pm 6.53$ \\
T2 & 50.02 & 62.1 & 60.4 & $54.90^{\mathrm{b}} \pm 11.78$ \\
T3 & 68.48 & 47.38 & 48.83 & $81.57^{\mathrm{a}} \pm 0.38$ \\
\hline
\end{tabular}

Table 4. The specific growth rate of white shrimp (L. vannamei) reared in probiotic-treated rearing water at three different concentrations.

\begin{tabular}{ccccc}
\hline \multirow{2}{*}{ Treatments } & \multicolumn{4}{c}{ Specific Growth Rate (\% BW/day \pm SD) } \\
\cline { 2 - 5 } & Day-7 & Day-14 & Day-21 & Day- 28 \\
\hline T0 & $0.71^{\mathrm{b}} \pm 0.44$ & $1.50^{\mathrm{a}} \pm 0.23$ & $1.41^{\mathrm{c}} \pm 0.21$ & $1.14^{\mathrm{c}} \pm 0.09$ \\
T1 & $1.40^{\mathrm{a}} \pm 0.22$ & $1.73^{\mathrm{a}} \pm 0.25$ & $1.84^{\mathrm{ab}} \pm 0.20$ & $1.45^{\mathrm{b}} \pm 0.26$ \\
T2 & $0.91^{\mathrm{ab} \pm 0.24}$ & $1.95^{\mathrm{a}} \pm 0.65$ & $2.08^{\mathrm{a}} \pm 0.55$ & $1.71^{\mathrm{b}} \pm 0.44$ \\
T3 & $1.35^{\mathrm{ab} \pm 0.37}$ & $1.73^{\mathrm{a}} \pm 0.14$ & $1.99^{\mathrm{ab}} \pm 0.18$ & $2.25^{\mathrm{a}} \pm 0.03$
\end{tabular}

This study used a Completely Randomized Design consisting of four treatments: T0 (without probiotic administration), T1 (probiotic administration at $10^{6} \mathrm{CFU} / \mathrm{ml}$ ), T2 (probitic administration at $10^{7} \mathrm{CFU} / \mathrm{ml}$ ), T3 (probiotic administration of $10^{8} \mathrm{CFU} / \mathrm{ml}$ ), and $\mathrm{SD}=\mathrm{Standard} \mathrm{Deviation}$. Superscripts with different letters indicate different in FCR values $(p<0.05)$. 
Uneaten feed, shrimp feces, and dead plankton are the main elements in the formation of organic matter in the rearing water. Microbes break down organic matter resulting in the production of new bacterial biomass, $\sim 40-60 \%$ of the organic material that is metabolized (Avnimelech, 2006).

On day $28^{\text {th }}$, organic matter at T0 treatment was lower than that of $\mathrm{T} 1$ treatment. This is due to the number of shrimps in the fourth week in the T0 tank was lower than the number of shrimps in T1. As a consequence, the amount of feed given in the T0 was lower, which resulted in lower amount of organic matter formed in $\mathrm{T} 0$ than in $\mathrm{T} 1$. Whereas the high organic matter in the T1 was due to the administred probiotic bacteria was unable to degrade the organic material produced by white shrimp. However, not all of the administered probiotics with higher density were able to degrade organic matter optimally. This was indicated by the rearing water in T3 $\left(10^{8} \mathrm{CFU} / \mathrm{ml}\right)$ where the amount of organic matter showed no significant difference than that of T0 (p $<0.05$ ). This result might be due to probiotic consortium in rearing water of $\mathrm{T} 3$ to compete with each other for obtaining nutrients.

Setiawati and Hudaidah (2013) explained that the high administration of probiotic bacteria could lead to competition in obtaining nutrients or substrates, which could be inhibit bacterial growth activities. This condition causes a decrease in the performance of probiotic bacteria in degrading organic matter. Furthermore, Boyd (2016) stated that organic matter containing higher nitrogen is easier to be broken down than organic matter with low nitrogen content. This might be due to the fact that the probiotic microorganisms required more nitrogen to produce their cells.

The conversion ratio (FCR) of shrimps in all treatments was lower than the control (T0) and was significantly different among treatments $(p<0.05)$. FCR in treatment T3 (1.22) was significantly different $(\mathrm{p}<0.05)$ from T1 (1.75) and T2 (1.87). In this study, the lowest FCR value was recorded at Treatment 3 (1.22).

The FCR was calculated from the total amount of feed consumed divided by the weight gain of shrimp during the culture period. The smaller the value of the FCR, the better the feed is utilized in shrimp growth. The average FCR of white shrimp feed is presented in Table 2.

The feed efficiency of white shrimp ranged from 38.36 to $81.57 \%$. Feed efficiency is the opposite of the feed conversion ratio. Feed efficiency is the percentage increase in body weight divided by the amount of food consumed. The higher the value of feed efficiency, the lower the value of feed conversion ratio, and vice versa. Higher value of feed conversion results in lower value of feed efficiency. The feed efficiency of shrimp in T0 (38.36\%) was significantly different from shrimp in T1 $(57.50 \%)$, T2 $(54.90 \%)$, and T3 $(81.57 \%)(\mathrm{p}<0.05)$. While feed efficiency in shrimps receiving T3 was significantly different shrimps from $\mathrm{T} 1$ and $\mathrm{T} 2(\mathrm{p}<0.05)$. The feed efficiency of white shrimp receiving probiotic supplementation could be seen in Table 3 .

The highest feed efficiency obtained in the present study was $81.57 \%$ in shrimps with T3 treatment, while the lowest in control $(\mathrm{T} 0)$, which was $38.36 \%(\mathrm{p}<0.05)$. These results show that the probiotic supplementation improved the feed efficiency of white shrimp. This result might be indicate that the probiotic bacteria are used by the white shrimp as a protein source for growth or the probiotic bacteria produce extracellular enzymes that help in shrimp digestion.

According to Pahlawi et al. (2019) Pseudomonas sp. could be produce protease, lipase, cellulase, and amylase enzymes. Whereas Bacillus sp. had been reported to secrete extracellular enzymes such as protease, amylase, and lipase (Karigar and Rao, 2011) hence it could be help the digesting process that takes place in the stomach. These enzymes help hydrolyze complex molecular nutrients such as breaking down carbohydrates, proteins, and fats into simpler molecules such as glucose, amino acids, and fatty acids. Furthermore, $\mathrm{Pu}-$ tra (2010) stated that the extracellular enzymes helped to hydrolyze complex molecular nutrients into simpler molecules to facilitate the process of digestion and absorption in the digestive tract of fish.

The specific growth rate of white shrimp during the culture period increased overtime. At day-28. the specific growth rate of shrimps in the control group (T0) was significantly different from shrimps at $\mathrm{T} 2$ and $\mathrm{T} 3$ but was not significantly different from shrimps in $\mathrm{T} 1 \mathrm{p}>$ 0.05 ). While the specific growth rate of shrimps at $T 3$ was significantly different from the specific growth rate of shrimp at T1 and T2 $(\mathrm{p}<0.05)$. The average specific growth rate of white shrimp supplemented with probiotic at the different concentrations is presented in Table 4.

The specific growth rate of white shrimp calculated on day- 28 in T3 treatment $(2.25 \%$ BW/day) was significantly higher than the white shrimp in control ( $\mathrm{T} 0$; $1.14 \% \mathrm{BW} /$ day). This result indicated that the administration of probiotics at $10^{8} \mathrm{CFU} / \mathrm{ml}$ (T3) improved feed digestion in the shrimp through extracellular enzyme production. The production of extracellular enzymes by the probiotics increased the digestibility of protein, carbohydrates, and fat so that the feed utilization 
and growth of the shrimp were higher than the control shrimps. This result is supported by a research result of Djauhari et al. (2016) in which the addition of probiotics at $10^{6}-10^{10} \mathrm{CFU} / \mathrm{g}$ of feed reduced the amount of feed needed for carp growth. In addition, Wang and $\mathrm{Gu}$ (2010) reported that the addition of L. acidophilus RS058, R. palustris GH642 and B. coagulans NJ105 as additives to rearing water increased the growth performance and immune response of white shrimp. Similarly, Setyono et al. (2019) explained that the application of biofloc and probiotics could increase the specific growth rate of white shrimp by $4.90 \%$.

Water quality parameters. including $\mathrm{pH}$. temperature, DO (Dissolved Oxygen). and salinity measured during the culture period is presented in Table 5.

Table 5. Water quality of shrimps' rearing water measured during 28 days

\begin{tabular}{ll}
\hline Water quality parameters & Average Values \\
\hline Temperature & $24.5-26.8^{\circ} \mathrm{C}$ \\
DO (Dissolved Oxygen) & $4.92-5.78 \mathrm{ppm}$ \\
$\mathrm{pH}$ & $7.1-8.0$ \\
Salinity & $26-30 \mathrm{ppt}$ \\
\hline
\end{tabular}

The average temperature of the shrimps' rearing water during the culturing period ranged from 24.5-26.8 ${ }^{\circ} \mathrm{C}$. The temperature was slightly below the tolerance limit for white shrimp, which is $26-35^{\circ} \mathrm{C}$ (WWF-Indonesia Fisheries Team. 2014). This is due to the cold weather of the rainy season therefore tends to cause the ambient temperature to decrease. The $\mathrm{pH}$ level ranged from 7.1 to 8.0 which was within the tolerance limits for white shrimp ranging from 7.0-8.5 (WWF-Indonesia Fisheries Team. 2014). Dissolved oxygen levels during the study ranged from 4.92 to $5.78 \mathrm{ppm}$ which was a safe range for white shrimp (4.4 to $5.4 \mathrm{ppm}$ ) as reported by Thakur and Lin (2002). The measured salinity during the study was between $26-30$ ppt. The salinity is still within the tolerance limits for white shrimp. According to Sulistinarto (2008) salinity tolerance of white shrimp ranges from 5 to $35 \mathrm{ppt}$.

\section{Conclusion}

The administration of probiotics (Pseudomonas sp. and Bacillus sp.) at different concentrations significantly affected the amount of organic matter, feed conversion ratio, feed efficiency, and specific growth rate of white shrimps. The lowest organic matter $(138.68 \mathrm{mg} / \mathrm{l})$ was obtained from probiotic administration at a concentration of $10^{7} \mathrm{CFU} / \mathrm{ml}$ (T2). While the administration of $10^{8} \mathrm{CFU} / \mathrm{ml}$ (T3) had the lowest feed conversion ratio (1.22), highest feed efficiency ( $81.57 \%)$, and the best specific growth rate of white shrimp $(2.25 \% \mathrm{BW} /$ day $)$.

\section{Acknowledgements}

Author(s) are grateful to Mr. Sugeng Rahardjo, B.Sc., the Head of Brackishwater Aquaculture Development Center, Jepara and Dr. Arief Taslihan, the Head of Fish and Environmental Health Laboratory for their support of during research activities and facilities during research in Brackishwater Aquaculture Development Center. Jepara.

\section{Authors' Contributions}

All authors have discussed the results and contributed from the start to the final manuscript; MJ, WHS: was responsible for the overall data collection and writing the initial until final draft of this paper. DDN, RZ: responsible for some data collection, particularly secondary data, and discussion of findings. MJ: besides being involved in a few field works. was also involved in the discussion of this paper.

\section{Conflict of Interest}

The authors do not have conflicts of interest.

\section{Funding Information}

This research was partially funded by the General Directorate of Research and Development. Ministry of Research, Technology \& Higher Education during 2019 with grant number of 6/E/KPT/2019 and 4/E1/KP.PTNBH/2019.

\section{References}

Adiwijaya, D., Supito \& Sumantri, I. (2008). Penerapan Teknologi Budidaya Udang Vaname (L. vannamei) Semi Intensif pada Lokasi Tambak Salinitas Tinggi. Jurnal Media Budidaya Air Payau BBPAP, 7: 19 hal.

Aslamyah, S. (2011). Kualitas Lingkungan dan Aktivitas Enzim Pencernaan Udang Vannamei (Litopenaeus vannamei) pada Berbagai Konsentrasi Probiotik Bioremediasi-Bacillus sp. Fish Scientiae, 1(2): 161-178.

Avnimelech, Y. (2006). Bio-filters: The need for an new comprehensive approach. Aquacultural Engineering, 34: 172-178.

Boyd, C. E. (2016). Decomposition and accumulation 
JIPK. Volume 12 No 1. April 2020 / Application of Probiotics for Organic Matter and Enhancement of Growth...

of organic matter in ponds. Global Aquaculture Advocate. https://www.aquaculturealliance.org/ advocate/decomposition-and-accumulation-of-organic-matter-in-ponds. $6 \mathrm{p}$.

Cha, J. H., Rahimnejad, S., Yang, S. Y., Kim, K. W., \& Lee, K. J. (2013). Evaluations of Bacillus spp. as dietary additives on growth performance, innate immunity and disease resistance of olive flounder (Paralichthys olivaceus) against Streptococcus iniae and as water additives. Aquaculture, 402-403: 50-57.

Dahlan, J., Hamzah, M., \& Kurnia, A. (2017). Pertumbuhan Udang Vaname (Litopenaeus vannamei) yang Dikultur pada Sistem Bioflok dengan Penambahan Probiotik. Journal of Fishery Science and Innovation, 1(1): 19-27.

Djauhari, R., Widanarni, Sukenda, Suprayudi, M. A., \& Zairin Jr, M. (2016). Characterization of Bacillus sp. NP5 and its Application as Probiotic for Common Carp (Cyprinus carpio). Research Journal of Microbiology, 11: 101-111.

Edy, M. H., \& Busono, E. (2000). Penerapan Probiotik Sebagai Upaya Kelola Lingkungan Internal Tambak Udang Windu (Penaeus monodon Fabr.) Untuk mencegah Kegagalan Panen. Makalah pada Dialog Solusi dan Aksi Penanganan Kematian Udang di Tambak di KRI Teluk Banten Ujung Surabaya. 8 hal

Effendi.(2003).Telaah Kualitas Air Bagi Pengelolaan Sumber Daya dan Lingkungan Perairan. Kanisius. Yogyakarta

Eissa, N., El-Gheit, E. A. \& Shaheen, A. A. (2014). Protective effect of Pseudomonas fluorescens as a probiotic in controlling fish pathogens. Americould be Journal of BioScience, 2(5): 175-181.

Ekasari, J. (2009). Teknologi Bioflok : Teori dan Aplikasi dalam perikanan budidaya sistem intensif. Jurnal akuakultur Indonesia, 8(2): 117-126.

Herdianti, L., Kadarwan, S., \& Sigid, H. (2015). Efektivitas Penggunaan Bakteri Untuk Perbaikan Kualitas Air Media Budi Daya Udang Vaname ( ${ }^{i-}$ topenaeus vannamei) Super Intensif. Jurnal Ilmu Pertanian Indonesia, 20(3): 265-271.

Irianto, A. (2003). Probiotik Akuakultur. Yogyakarta: Gajah Mada University Press. 125 hal.

Karigar, C. S \& Rao, S. S. (2011). Role of microbial enzymes in bioremediation of pollutans: A review. Enzyme Research, : 1-11.

Kumar, N. J. P., Srideepu, K., Reddy, M. H., \& Reddy, K. V. S (2016). Effect of water probiotic (Pro-W) on Litopenaeus vannamei culture ponds of Nellore,
Andhra Pradesh, India. International Journal of Environmental Sciences, 6(2): 846-850.

Kusriningrum, R. S. (2008). Rancould began Percobaan. Surabaya: Airlangga University Press. 274 hal.

Linggarjati, K. F., Djunaedi, A., \& Subagiyo. (2013). Uji Penggunaan Bacillus sp. sebagai Kandidat Probiotik untuk Pemeliharaan Rajungan (Portunus sp.). Journal of Marine Research, 2(1): 3-6

Nur, A. (2011). Manajemen Pemeliharaan Udang Vaname. Jepara: Balai Besar Pengembangan Budidaya Air Payau Jepara. 40 hal.

Pahlawi, I. M. H., Satyantini, W. H., \& Sudarno. (2019). Uji Patogenitas Bakteri Pseudomonas sp. pada Udang Vaname (Litopenaeus vannamei) Sebagai Kandidat Probiotik. Journal Aquaculture and Fish Health, 8(2): 92-98.

Putra, A. N. (2010). Kajian Probiotik, Prebiotik dan Sinbiotik untuk Meningkatkan Kinerja Pertumbuhan Ikan Nila (Oreochromis niloticus). Tesis. Bogor: Institut Pertanian Bogor. 109 hal.

Putra, S. J. W., Mustofa, N., \& Niniek, W. (2014). Analisis Hubungan Bahan Organik dengan Total Bakteri pada Tambak Udang Intensif Sistem Semibioflok di BBPBAP Jepara. Jurnal of Maquares, 3(3): 121129

Rengpipat, S., Rueangruklikhit, T., \& Piyatiratitivorakul, S. (2008). Evaluation of lactic acid bacteria as probiotics for juvenile seabass Lates calcarifer. Aquaculture Research, 39: 134-143.

Setiawati, J. E., \& Hudaidah, S. (2013). Pengaruh Penambahan Probiotik pada Pakan dengan Dosis Berbeda terhadap Pertumbuhan, Kelulushidupan, Efisiensi Pakan dan Retensi Protein Ikan Patin (Pangasius hypophthalmus). e-Jurnal Rekayasa dan Teknologi Budidaya Perairan, 1(2): 152-162.

Setyono, B.D.H., Fariq, A., \& Paryono. (2019). Pengaruh Aplikasi Bioflok yang Dikombinasi dengan Probiotik Terhadap Performa Pertumbuhan Udang Vaname. Buletin Veteriner Udayana, 11(1): 7-13.

Standen, B. T., Peggs, D. I., Rawling, M. D., Foey, A., Davies, S. J., Santos, G. A., \& Merrifield, D. J. (2015). Dietary administration of commercial mixed-species probiotic improves growth performance and modulates the intestinal immunity of tilapia, Oreochromis niloticus. Fish \& Shellfish Immunology, 49: 427-435.

Suharyadi. (2011). Budidaya Udang Vaname (Litopenaeus vannamei). Jakarta: Pusat Penyuluhan Kelautan Perikanan. 60 hal.

Sulistinarto, D. (2008). Manajemen Pemeliharaan Budidaya Udang Berwawasan Lingkungan. Jepara: 


\section{Balai Budidaya Air Payau.}

Thakur, D. P. \& Lin, C. K. (2002). Water quality and nutrient budget in closed shrimp (Penaeus monodon) culture systems. Aquacultural Engineering, 27: 159-176.

Tim Perikanan WWF-Indonesia. (2014). Better Management Practices Seri Panduan Perikanan Skala Kecil Budidaya Udang Vannamei Tambak Semi Intensif dengan Instalasi Pengolahan Air Limbah (IPAL). Edisi 1. Jakarta: WWF-Indonesia. 38 hal.

Wang, Y. B., Tian, Z. Q., Yao, J. T., \& Li, W. F. (2008). Effect of probiotics, Enteroccus faecium, on Tilapia (Oreochromis niloticus) growth performance and immune response. Aquaculture, 277: 203-207.

Wang, Y., \& Gu, Q. (2010). Effect of probiotics on white shrimp (Penaeus vannamei) growth per formance and immune response. Marine Biology Research, 6: 327-332.

Widagdo, P. (2011). Aplikasi probiotik, Prebiotik dan Sinbiotik melalui Pakan pada Udang Vaname ( $\mathrm{Li}-$ topenaeus vannamei) yang Diinfeksi Bakteri Vibrio harveyi. Skripsi. Fakultas Perikanan dan Ilmu Kelautan. Bogor: Institut Pertanian Bogor. 29 hal.

Yudiati, E., Arifin, Z., \& Riniatsih, I. (2010). Pengaruh Aplikasi Probiotik terhadap Laju Sintasan dan Pertumbuhan Tokolan Udang Vanamei (Litopenaeus vannamei), Populasi Bakteri Vibrio, serta Kandungan Amoniak dan Bahan Organik Media Budidaya. Ilmu Kelautan, 15(3): 153-158.

Yuvaraj, D., \& Karthik, R. (2015). Efficacy of Probiotics on Litopenaeus vannamei Culture through Zero Water Exchange System. Journal of Fisheries and Aquatic Science, 10(6): 445-463. 